\title{
INTRODUCTION TO THE SYMBOL-IDENTIFICATION OF THE PRESENCE OF WATER IN IRAN'S MOSQUES ARCHITECTURE
}

\author{
Parya Narimani \\ Department of Architecture, East Azarbaijan Science and Research Branch, Islamic Azad University, \\ Tabriz, Iran \\ pariya.narimani@yahoo.com \\ Hassan Sattari Sarbangholi \\ Department of Architecture, Tabriz Branch, Islamic Azad University, Tabriz, Iran \\ sattari@,iaut.ac.ir
}

\begin{abstract}
Water element in Iranian architecture in terms of symbolic meanings and concepts has been manifested in different forms. Water in the body of Iranian mosques due to both the mystical and practical loads had also carried more symbolic messages. The presence of water in Iranian mosques architecture In addition to having image-creations associated with the prayers, ablution, purification and refreshing ritual had also carried reflection of semantic load, transparency, and being-like-mirror.Water in terms of presence in running and still water forms and in terms of symbolism system in the methods of allusion, symbol, sign, indication, secret, mystery, point, appearance, riddle, analogy has found objective appearancein the body of Iranian mosques. The present research has been conducted with descriptive-analytical method.The presence of water is in a variety of ordering elements of kinetic and stillness, and signs of relaxation, peace, reconciliation, stable sign of life, sky reflection, and survival continuation in ideas derived from symbolic concepts. The most important elements related to the presence of water in Iranian mosques architecture are place of ablution, trough, pool, patio, and fountain. This appearance and manifestation of water's form and character in Iranian architecture have had a special position and even sacred. A corner of these appearances can be observed in symbols used in Iranian mosques objectively. Symbol, its types and the manner of advent and display of the symbolic elements of water in Iran's mosque architecture have been investigated in this study. Achievements of this research will lead to the initial symbol-identifier conception of the presence and manifestation and appearance of water in the area of the architectural body of Iranian mosques.
\end{abstract}

Keywords: architecture design, mosque, mosques architecture, Iran water, symbol

\section{İRAN CAMİ MIMARISINNDE SU GÖSTERGESİ SEMBOLÜNÜN TANIMLANMASI}

ÖZ

Sembolik anlamlar ve kavramlar açısından İran mimarisinde su sembolü mistik ve pratik yükleri taşır. Sembolik mesajlar nedeniyle İran camilerinde farklı biçimler yer alır. Dualar, abdest, saflaştırma ve ferahlatıcı ritüel bir ilişkili durum yarattıkları gözlemlenmektedir. İran cami mimarisinde suyun varlığ 1 semantik yük, şeffaflık ve ayna olmak gibigibi birçok forma işaret edmektedir. Sembol, çeşitleri, gelişi ve 
İran'ın cami mimarisinde su sembolik unsurları bağlamında çalışma incelenmiştir. Bu araştırmada İran camilerinin mimari vücudun alanında varlığı ve tezahürü ve suyun görünümünün ilk sembolü-tanımlayıc1 anlayışına yol açmaktadır.

Anahtar Kelimeler: mimari tasarım, cami, camiler mimarisi, Iran su, sembol

\section{INTRODUCTION}

Mosques are one of the most prominent and the most advanced elements of Islamic city. They are a manifestation of the perfection and holiness. This holy place reaches the human soul to the eternal truth and true perfection. Mosques are the place of obedience and worship. The human must purify his body to enter this divine and holy space for being able to prepare his soul to be infinite by entering this place. Blue that can be seen in arabesque and Islamic symbols in mosques indicates that as the main color of Iranian mosques is associated with the symbol of water and sky. The audiences feels calm when see this color. It also induces the symbol of purity.

Everyone knew a symbol as the representative of God ... and saw God manifested in that symbol... "light", "water", "Brightness", "Fire", which gave warmth and life and be constructive... each group of people with an understanding of God ..., comes together. And a symbol that they knew as the representative of God became a symbol of their belief and the sign of their group (Khosravi, 1999, 150). God makes water conquered for the human as well as other natural phenomena, but this dominance is potential. Water for Iranians, like other elements in Iran's rebellious nature is steed, sometimes cantankerous and sometimes tame. The human must know him and know his language and imprison him and force him to build up and create and keep the city (Ghaiyoomi Bid Hendi, 2009, 4).

Water is a natural element that has had a specific contribution in the formation and creation of architectural monuments. At the beginning, water was considered as the only substance for thirstquenching and source of life, but over time took also another role. Water has known in all cultures as purity and cleanliness factor. In Iran, due to drought of the land and religious teachings, it has been taken a specific holiness (Ali Pourmand, 2014, 1).

Aban and Anahita. Aban is the name of the water angle that people knew the sentry of the eighth month of the year and the tenth day of each month as the duty of this angel. Arodvī sūra Anahita is the female goddess of all water on earth and the source of the cosmic ocean (Aryaee, 2005, 102).

Fountain is one of the important elements to complete the central courtyard. Fountain in the Islamic period, in addition to its architectural role - the formation of a soft bed - and create a sense of unity with the bodies, had been a place for performing ablutions and cleanliness before entering the holy place. On the esplanades and public places, division of the spaces was being determined by creating creek, and the shape and the route were being determined by its relationship with the fountain. In an era, they have brought the fountain into the building, and contributed to the unity of the building components by this element (Sadigh, 2535, 125).

The courtyard has an important role in the mosques. This place due to the physical features, the presence in it is possible in most seasons of the year. The courtyard of the mosque due to the presence and symbolic importance of water and creation of the fountain is somehow linked to the Islamic gardens. Water whether flowing or still, always has been present in the mosque. Indeed, the presence, the different states of water is different interpretations of the nature and somehow the essence of God because nature is the mirror of the essence of reality and is respected as the sign of essence of God. 
Flowing water is present in most mosques. Some instances of flowing water can be seen in Grand Mosque of Natanz, Naeen and Mohammedie, that is as a symbol of purity. Flowing water becomes still water in the pool of courtyard of the mosque. On the one hand a calm surface of water reflects the image of the sublime paradise and on the other hand is the cooling agent of the air and stylizing agent of the courtyard of the mosque. In addition, the pool is the place of performing ablutions and purification (Inanloo Daeeloo, Farokhi, 2001, 42).

Mythical thoughts of Persian about water are as follows: 1- Mental Purification 2- Washing for invocation 3- Water of life 4- Fertility and abundance. (Toghyani, Ghorbani, 2011, 1). As can be seen in the foregoing, purify of the soul and spirit means water causes purification of the contaminated spirits and spiritual purification, that is exactly "what the Muslims are doing in the first step when enter the mosques.

\section{RESEARCH METHODS}

The research method is descriptive-analytic. It has been conducted by reviewing, analyzing and combining the study histories on the subject. The conventional methods of collecting information ranging from documents and field have been used to conduct the study. Investigation of the theoretical principles of the subject has been discussed in the section of library studies. Then the concepts of symbol, and water, and their manifestation in the Iranian mosques architecture have been examined in the second step.

Table 1: Explanation of the cases related to the methods in the context of research

\begin{tabular}{|c|c|}
\hline $\begin{array}{c}\text { Research } \\
\text { stanec }\end{array}$ & $\begin{array}{c}\text { Stages of conducting the research and tools used in the } \\
\text { ftudv }\end{array}$ \\
\hline first stage & Library Studies and examination of the theoretical \\
\hline second & Derivation of the concepts of symbol and water \\
\hline $\begin{array}{c}\text { second } \\
\text { stage }\end{array}$ & $\begin{array}{c}\text { Analysis and investigation of water manifestation in } \\
\text { Iranian mosques architecture }\end{array}$ \\
\hline
\end{tabular}

Table 1 Source: from the authors

RESEARCH BACKGROUND

- Theory histories on water

Table 2: theory histories

\begin{tabular}{|c|c|c|c|c|}
\hline Date & Authors & Title & Publisher & Conclusion \\
\hline 1394 & $\begin{array}{c}\text { Nader } \\
\text { Ardalan, } \\
\text { Bakhtiar } \\
\text { Laleh }\end{array}$ & $\begin{array}{c}\text { The sense of } \\
\text { unity of the } \\
\text { role of } \\
\text { tradition in }\end{array}$ & $\begin{array}{c}\text { Translated by } \\
\text { Jalili Vandad, } \\
\text { Fifth Printing, } \\
\text { Tehran: Royal }\end{array}$ & $\begin{array}{c}\text { Architectural tools related to sun, wind } \\
\text { and water as a metaphor for applying } \\
\text { beauty offer a perfect personality. }\end{array}$ \\
\hline $\begin{array}{c}\text { Ali } \\
\text { Pourmand, } \\
\text { Hasan } \\
\text { in the } \\
\text { presence of } \\
\text { water }\end{array}$ & $\begin{array}{c}\text { Architecture } \\
\text { Book, June } \\
\text { 2014, Issue 189 }\end{array}$ & $\begin{array}{c}\text { The point where the water goes out } \\
\text { turns into a volume with the meaning } \\
\text { of the identity of a neighborhood or } \\
\text { city. Architect creativity in relation to } \\
\text { the concept of water had been often in } \\
\text { the city in desert, especially in Isfahan, } \\
\text { Yazd, Nain, and Kashan. }\end{array}$ \\
\hline 1390 & $\begin{array}{c}\text { Mahmoudi } \\
\text { Nejad, Hadi }\end{array}$ & $\begin{array}{c}\text { Bio-based } \\
\text { architecture }\end{array}$ & $\begin{array}{c}\text { Tehran, Hele, } \\
\text { Thahan, Second } \\
\text { Printing }\end{array}$ & $\begin{array}{c}\text { The emphasis is on more } \\
\text { contemplation on the nature around us. } \\
\text { The human feels himself in the bosom } \\
\text { of nature since his creation. He has not } \\
\text { found a better way than coexistence }\end{array}$ \\
\hline
\end{tabular}




\begin{tabular}{|c|c|c|c|c|}
\hline & & & & $\begin{array}{l}\text { with the environment to survive. He } \\
\text { has accepted the nature as a wise } \\
\text { teacher to achieve his demands. }\end{array}$ \\
\hline 1388 & $\begin{array}{l}\text { Ghaiyoomi } \\
\text { Bid Hendi, } \\
\text { Mehrdad }\end{array}$ & $\begin{array}{l}\text { From tears to } \\
\text { swamp modes } \\
\text { of the } \\
\text { presence of } \\
\text { water in the } \\
\text { city in Persian } \\
\text { prose texts }\end{array}$ & $\begin{array}{l}\text { Safeh, Spring } \\
\text { and Summer in } \\
2009,18 \text { th } \\
\text { period, Issue } \\
48, \text { pp. 53-64 }\end{array}$ & $\begin{array}{l}\text { What has created the status of water in } \\
\text { the Iranian city is a series of factors } \\
\text { ranging from imagination and } \\
\text { mentality of Iranians to physical and } \\
\text { geographical factors. The status of } \\
\text { water in the Iranian city is a series of } \\
\text { mentality and outness. Recognizing } \\
\text { the relationship between water and the } \\
\text { Persian city requires recognizing this } \\
\text { phenomenon at all levels, from } \\
\text { imagination to reality. }\end{array}$ \\
\hline 1388 & $\begin{array}{l}\text { Mansoori, } \\
\text { Amir }\end{array}$ & $\begin{array}{c}\text { Water } \\
\text { Architecture }\end{array}$ & $\begin{array}{l}\text { Manzar, } \\
\text { November 2009, } \\
\text { Issue } 1\end{array}$ & $\begin{array}{l}\text { Human understanding from } \\
\text { environmental phenomena such as } \\
\text { water at the beginning was a reaction } \\
\text { to meet his vital needs. Water is a } \\
\text { substance that human life depends on } \\
\text { it. Water is a condition of survival. }\end{array}$ \\
\hline
\end{tabular}

Table 2 Source: According to sources cited by the author

\section{- Theory histories on symbol}

Table 3: Theory histories

\begin{tabular}{|c|c|c|c|c|}
\hline Date & Authors & Title & Publisher & Conclusion \\
\hline 2015 & $\begin{array}{l}\text { Lütfiye } \\
\text { GÖKTAS } \\
\text { KAY } \\
\text { A }\end{array}$ & $\begin{array}{c}\text { Semiology in the } \\
\text { teaching of } \\
\text { history of art }\end{array}$ & $\begin{array}{c}\text { Procedia - } \\
\text { Social and } \\
\text { Behavioral } \\
\text { Sciences } 174 \\
\text { (2015) } 3350 \\
\quad-3357\end{array}$ & $\begin{array}{l}\text { Art is a communication tool that is } \\
\text { relevant to humans. Making an } \\
\text { effective communication depends on } \\
\text { the use from common language of both } \\
\text { parties and understanding each other. } \\
\text { Most of the contents of this article are } \\
\text { on the relationship between art history } \\
\text { and semiology. The symbol is a } \\
\text { svnthetic nominal indicator. Art is an }\end{array}$ \\
\hline 2015 & $\begin{array}{c}\text { Elena Gagiu } \\
\text { Pedersen }\end{array}$ & $\begin{array}{l}\text { Semantics of the } \\
\text { symbol: main } \\
\text { theories about the } \\
\text { symbol and the } \\
\text { themes of } \\
\text { symbols in } \\
\text { Alexandru } \\
\text { Macedonski's } \\
\text { poetry }\end{array}$ & $\begin{array}{l}\text { Procedia - } \\
\text { Social and } \\
\text { Behavioral } \\
\text { Sciences } 180 \\
\text { (2015) } 586 \\
\quad-592\end{array}$ & $\begin{array}{l}\text { This article proceeds to the semantic } \\
\text { structure of symbol in theory and } \\
\text { practice. It has studied the main } \\
\text { theories on the symbol (symbol), and } \\
\text { then investigates symbol in Alessandro } \\
\text { poetry. }\end{array}$ \\
\hline
\end{tabular}

Table 3 Source: According to sources cited by the author

Among the studies conducted on the water, and were investigated as research background by the authors of this article, no example was found that has exactly examined water in Iranian mosques architecture from the perspective of physical and spatial semiology. 


\section{ARCHITECTURAL DESIGN}

Architecture is a need and proportionality... as a garment is worn ... that if be tight, it would not fit the man, and if to be worn hardly, it would not cause anything except the inconvenience and shortness. (Khosravi, 1999, 168) In the architectural design process, the interaction between the individual, the creative process and creative product within a creative environment should be considered as a general rule in evaluating creativity. (.et al, 2015, 5 nazidizaj,) In architectural design, where architects' attention is on the inner dimension of architecture body, "semantic approach" is introduced.

Semanticism is attending to the meaning and conscience that is more than the attention to the face and appearance. (Bemanian, Azimi, 2010,2) Architectural design of the mosque was performed in the past on the basis of intellect, emotion and intuition and by balancing and making interaction between three elements of space, structure and human. Its aim was influencing the human spirit and soul, and relied on fundamental principles of architectural design including human suitability and dimensions, order, beauty and scale. (Cantaloupe, 2001, 183)

\section{MOSQUE}

Mosque is a signifier that can be asserted as a statement. This dominant statement or signified signifier induces spirituality and power. Mosque is considered as a statement that a speaker has produced it for a reader in a particular time and place (Rabiee, 2014, 270)

Mosque is a place requires calm, focus and induction the spirit of spirituality, so remembrance of God is manifested in it and it finds its own special dignity (Nicholas, 1976, 12). Light and water are the most similar material creatures to perfect human beings reality and to the reality of the mosque. They are the epitome of purity and spirituality. Therefore these two should be placed at the heart and center of the mosque and its components (Mofid, Reiszade, 1999, 668). Iranian mosque indicates parity in architecture. Mosque is the manifestation of nominal marriage, and the symbol of reaching to equilibrium in the field of architectural art (Mofid, Reiszade, 1999, 606). Mosque architecture is the sensitive issues of architectural art, because is the place of human soul interaction with the higher levels of universe of existence. Mosque architecture can be involved and effective in relevant human existence relationship with the higher levels of existence. It can facilitate spiritual and mystical perceptions (Fatahi, Omranipour, 2014, 2).

\section{IRANIAN MOSQUES ARCHITECTURE}

After the fall of the Sassanids, construction of mosques began in Iran. In the first three centuries of Islamic rule in Iran, mosques were built with very simple method and follows Sassanids architecture. Khorasan is considered as the birthplace of the earliest examples of Islamic architecture in Iran, so the way of constructing the buildings of this era (including Umayyads, Abbasids, and Thaherids) is known as Khorasani method. In this method that the public map of its monuments has been derived from early Islamic mosques, mosques have been constructed as "bedchamber" or "forty columns" (Zekrgoo, 46: 2001). In Islamic Iran, we are faced with bedchamber mosques, single veranda, double veranda, four verandas and combination of dome home with the original veranda (Abuzari, 2001: 117).

Presence of water in each of these Iranian mosques architecture patterns had been different in that place. For example, laver was used for ablution place in Safavid and Qajariyeh mosques. The obvious example of it can be observed in mosques in Isfahan (Imam Mosque) while ablution place is used in some traditional mosques.

\section{WATER}

Water is "blessing" and thus this divine blessing should not be contaminated, and should not be lavish, and vice versa we should be thankful for consuming it. Thanksgiving also means consuming the blessings where makes the benefactor to be revealed (Tabatabaei, 1978 and Motahari, 1988). 
Cold and wet water is symbolically known life-giving that favors rain magnanimously water is the element that refines life, and returns it to its eternal state. In addition, water is also a symbol of revelation in Islam. Certainly by performing ablution with water, he symbolically joins to his eternal state. Water is distributing and all its shapes are temporary. It allows material to be formatted and dispersed in the water form (Ardalan, Bakhtiar, 2015, 89).

Table 4

\begin{tabular}{|c|c|}
\hline $\begin{array}{c}\text { Flowing } \\
\text { water }\end{array}$ & It is the sign of life stability \\
\hline $\begin{array}{c}\text { Still } \\
\text { water }\end{array}$ & It refers to refers tranquility, peace and reconciliation \\
\hline $\begin{array}{c}\text { Pool } \\
\text { water }\end{array}$ & It is as a reflection of the sky and follows the sign of the \\
continuity of life
\end{tabular}

Table 4 Source: Based on (Khosrojerdi, Mahmoudi, 2014, 11) from authors

Before entering the mosque, contemplate in front of the water that is the key to close to God and to intone with Sweetheart, and the guide of servant in front of its majesty. As washing the superficial contamination with water, wash your sins with water of Divine mercy. Know that the life of everything is from water, so make your heart alive with it. Then think about the purity of water, the subtility of water, water purification, the blessing and the softness of water, its mingling with anything, and ornament your soul with these attributes. Purify your members by its purity, and subtilize the members by its subtility, liberate them from greatness of disobedience, subtilize all its purification and blessing in all your members. So communicate with the people of God like water, mingle with all people, give the right of everyone and everything to him or it, but beware to be changed in the meaning of self-servant (Ali Abadi, 1999, 315).

\section{INVESTIGATION OF THE WATER ELEMENT MANIFESTATION}

At first glance on the water element, you encounter with a simple and primary division of its manifestations and dutifulness in various rituals which are mentioned below:

\section{Diagram 1: mystery of water}

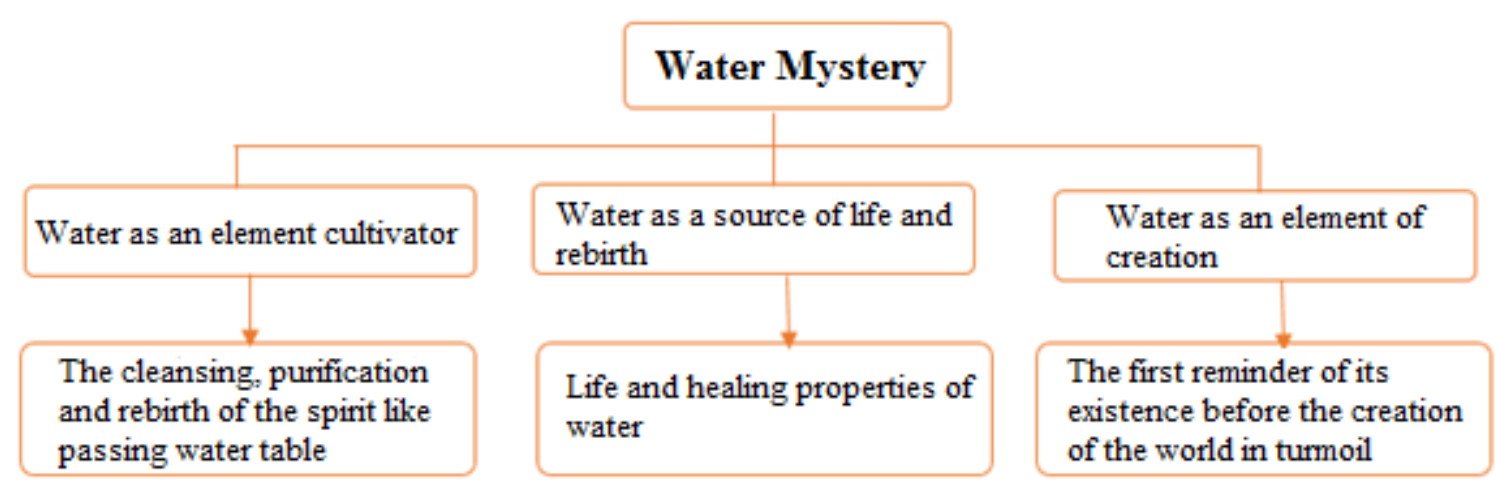

Diagram 1: source is based on (Mohseninia, Amiri Far, 2014, 5) from the author

Water is an element that has been used abundant in mysterious expression of Islamic Iranian architecture and in right side and matches the reality of its existance (Colman, s, 2003, 34). Water mystery in this architecture is a mirror ball of the world and the transmutation of the material world in allegorical forms. (Carl gustav, 1971, 34) 


\section{SYMBOL}

Symbolism of language expresses a knowledge that has been obtained by wisdom means mysticism (Ardalan, Bakhtiar, 2015, 35). Not only tangible forms are the manifestation of spiritual forms in the material world but also as Seyyed Hossein Nasr believes "tangible knowledge of this world that is globalization, itself is a symbol of rational knowledge of that world, and physical world is also a mysterious symbol and sign of spiritual and heavenly world "(Articles Collections of the conference on mosque architecture, 1999, 314).

There are two basic types symbol: natural and obvious. Natural symbols are natural processes that create certain regular systems which are symmetrical and balanced, or both. Obvious symbols are special symbols that have been enshrined by various traditions of the world and are changed by their update language and form (Ardalan, Bakhtiar, 2015, 36).

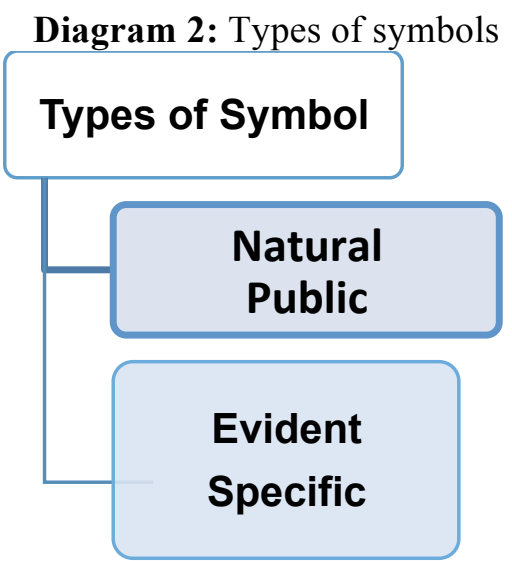

\section{Diagram 2 Source: Based on (Dad, Sima, Dictionary of Literary Terms, 1996, 302) from authors}

Pythagorean aphoristic sentences "Sumbula Ptagurya" were called Prohibiting sentences which were as the rules of practical behavior and their literal interpretations were understandable, but the exact meaning of these terms were understood by those knew their mystery, and allegorical sense is highlighted from the meaning of symbol. (Ritter, founder, \& Gabriel, 1998, p 7)

Symbol has been translated in different meanings in Persian language. Other translations of symbol are "symbol (Namad)". Symbol (Namad) that is a new word in Persian language and has no history in ancient literature, has been derived from Nemaudan, Namaeedan, Namayesh. With words like "Nemudgar" ${ }^{1}$ in memory of the Persian language, this word could be appropriate translation for symbol (Hosseini dastjerdi, 2013, 3).

Diagram 3: The meanings of symbol in Persian language

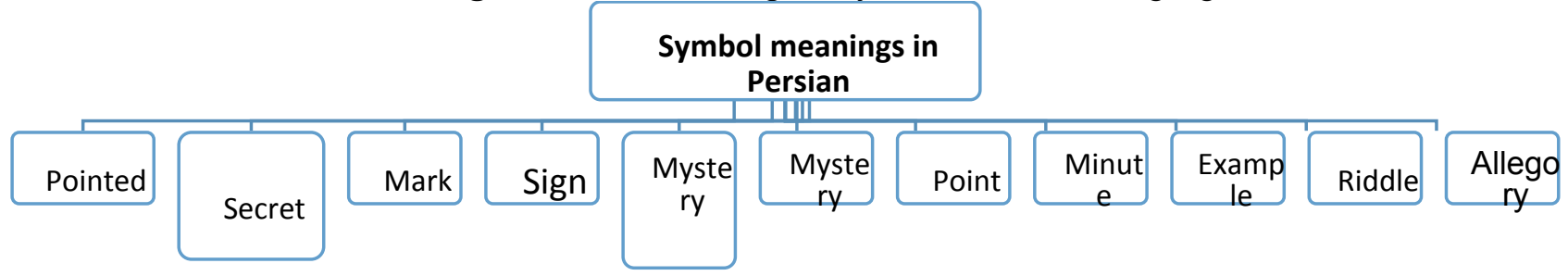

\footnotetext{
${ }^{1}$ It has been come below this word in Dehkhoda dictionary: Nemudgar] No / Ne [(compound) example and sign: the human body with his brief is an example of the entire universe that there is a symbol of all the things that He has created in the world in human being (Kimiaye Saadat).
} 
Figure 3 Source: Based on (Hosseini dastjerdi, 2013, 3) from authors

Diagram 4: The meaning of symbol in philosophical concepts dictionary

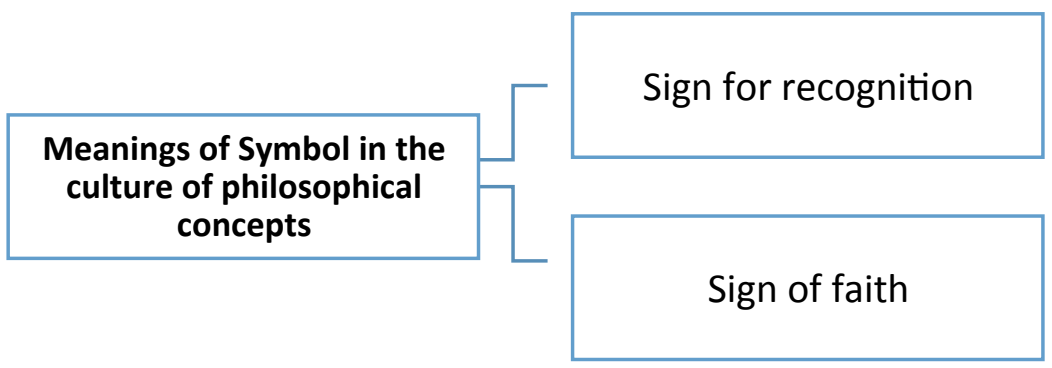

Figure 4 Source: Based on (Hosseini dastjerdi, 2013, 3) from authors

Symbol (mystery, sign or symbol or proverb of verse) is a special kind of expression that a speaker uses it not in the sense of symbol or instance of the instance or the symbol, but is the meaning which is at the heart of symbol, a meaning that cannot be understood by itself by human due to its abstract nature. However, due to tangibility and concreteness of symbol, it is understandable and comprehensible for the listener. For similar reasons the aim of God from the creation of the nature and natural phenomena are not the instances of natural phenomena, but are the meanings and concepts which are understandable and comprehensible for mankind in this way. They are manifestations of the beauty of God that are visible in the mirror of pure heart, as well as in the mirror of natural phenomena (see Ibn Arabi, Fotouhat, vol. 1, 174) (Articles Collections of the Conference on mosque architecture, 2009, 314). Symbol is also one of the literary arrays that obvious features of it have been noted in following diagram. Symbol means that meaning and purpose in symbolic language is not appearance and figure of speech, but is a conception beyond its appearance and beyond and deeper than it (Sharifian, Darbidi, 2007, 1).

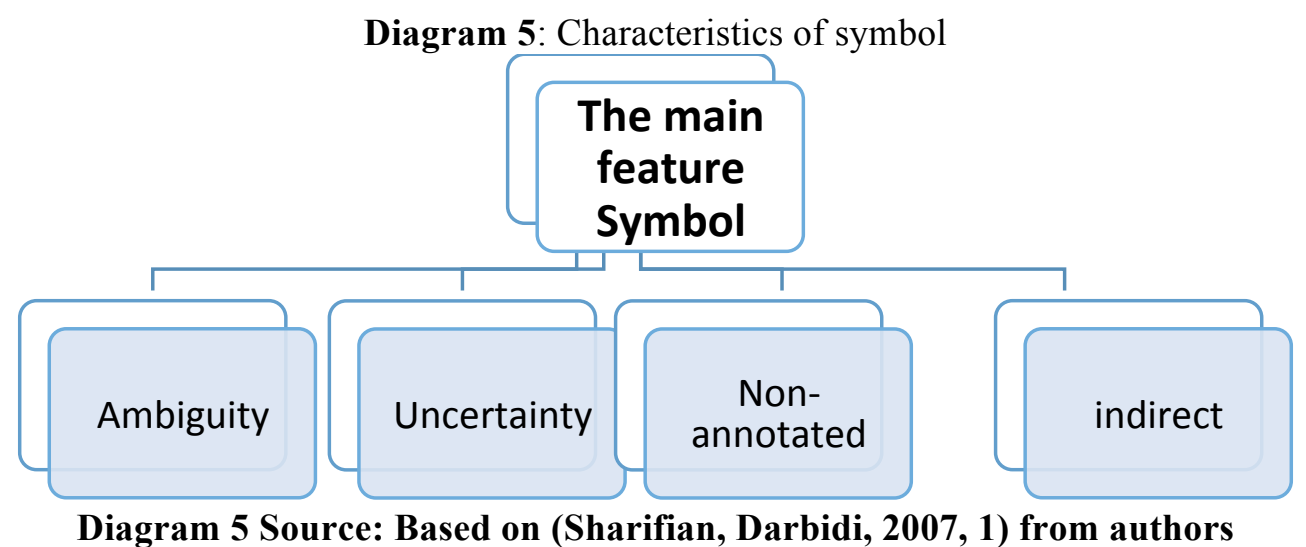

The views of some people on symbol have been expressed in the following table.

Table 5: views on symbol

\begin{tabular}{l|r} 
Author & View
\end{tabular}




\begin{tabular}{|c|c|}
\hline Günay & $\begin{array}{l}\text { Symbol is never intractably and null. They need to receive, analyze and } \\
\text { understand. Thus they need for a more exact knowledge. Symbol is caused by the } \\
\text { result of the relationship between the indicators and the subject. Symbol } \\
\text { understanding depends on the learning of object, and analysis of symbol depends }\end{array}$ \\
\hline Dragomirescu & $\begin{array}{l}\text { Symbol is the form of expression by which an abstract idea is easily understood } \\
\text { and expressed with the help of the name of an object belongs to the physical } \\
\text { world on the basis of an analogy. (Dragomirescu, 1995: 255) }\end{array}$ \\
\hline Goktas kaya & $\begin{array}{l}\text { Symbol as a definition is "a sign that is appeared through thought and } \\
\text { expression". This sign can be as a figure, an object, an indicator or a word. } \\
\text { Symbols are visual and aural facts and expression of things more than display. } \\
\text { However, "symbol" as a sign that has no causality relationship, and has not been } \\
\text { built over natural relationships. (Goktas kaya, 2015, 2.( }\end{array}$ \\
\hline Chambers & $\begin{array}{l}\text { He has meant symbol : "Bringing together to compare and inference" } \\
\text { "symbol in religious sense: is a selection and compend of a doctrine or a kind of } \\
\text { religious practices in the Eucharist" (Chambers, 1900, 519) }\end{array}$ \\
\hline $\begin{array}{l}\text { Liddell \& } \\
\text { Scott }\end{array}$ & $\begin{array}{l}\text { symbol is said as half of a coin or anything else, that is, two people who halve that } \\
\text { object among themselves, make a treaty or contract with each other and each } \\
\text { parties kept a part to himself (Liddell \& Scott, 1940, 663) }\end{array}$ \\
\hline Walter Muri & $\begin{array}{l}\text { He counts three main usages for the word of symbol in ancient times: 1- sign of } \\
\text { hospitality, 2- legal sign of rights granted to a foreigner and 3- Absolute of sign } \\
\text { (Muri. 1976.13r }\end{array}$ \\
\hline Corbin & $\begin{array}{l}\text { Language and expression of art and architecture of Iran and its consequences } \\
\text { includes symbols (Namad) and symbols. Corbin has written about language of } \\
\text { symbols (Namad) in Islamic culture and art: "In the same way that ordinary } \\
\text { language is part of the knowledge that is obtained through discursive reason and } \\
\text { the senses; the language of symbols (Namad) indicates a knowledge that is } \\
\text { acawired throwoh wisdom which is coonition The svmbols (Namad) are }\end{array}$ \\
\hline $\begin{array}{c}\text { Seyyed } \\
\text { Hossein Nasr }\end{array}$ & $\begin{array}{l}\text { Among theologians, mystery and allegory, or mysterious and allegorical language } \\
\text { is not something contrived and artificial. "Mystery and allegory in the sense that } \\
\text { the Europeans calls it Symbol, is never made by human mind, but is a true } \\
\text { reflection of the upper world in a lower level of existence» (Nasr, 1980, 406) }\end{array}$ \\
\hline
\end{tabular}

Table 5 Source: According to sources cited by the authors

\section{Preliminary Table of semiology of how the presence of water is in Iranian mosques architecture ${ }^{2}$}

\footnotetext{
${ }^{2}$ Water pond, padiav (washing and purifying a thing with praying), ablution building, large and small lavers, fountains, all have had different portraits of common symbolic symptoms in architectural language in the body of Islamic mosques in Iran
} 
Diagram 6: Introduction to the semiology of the presence of water in Iranian mosques architecture

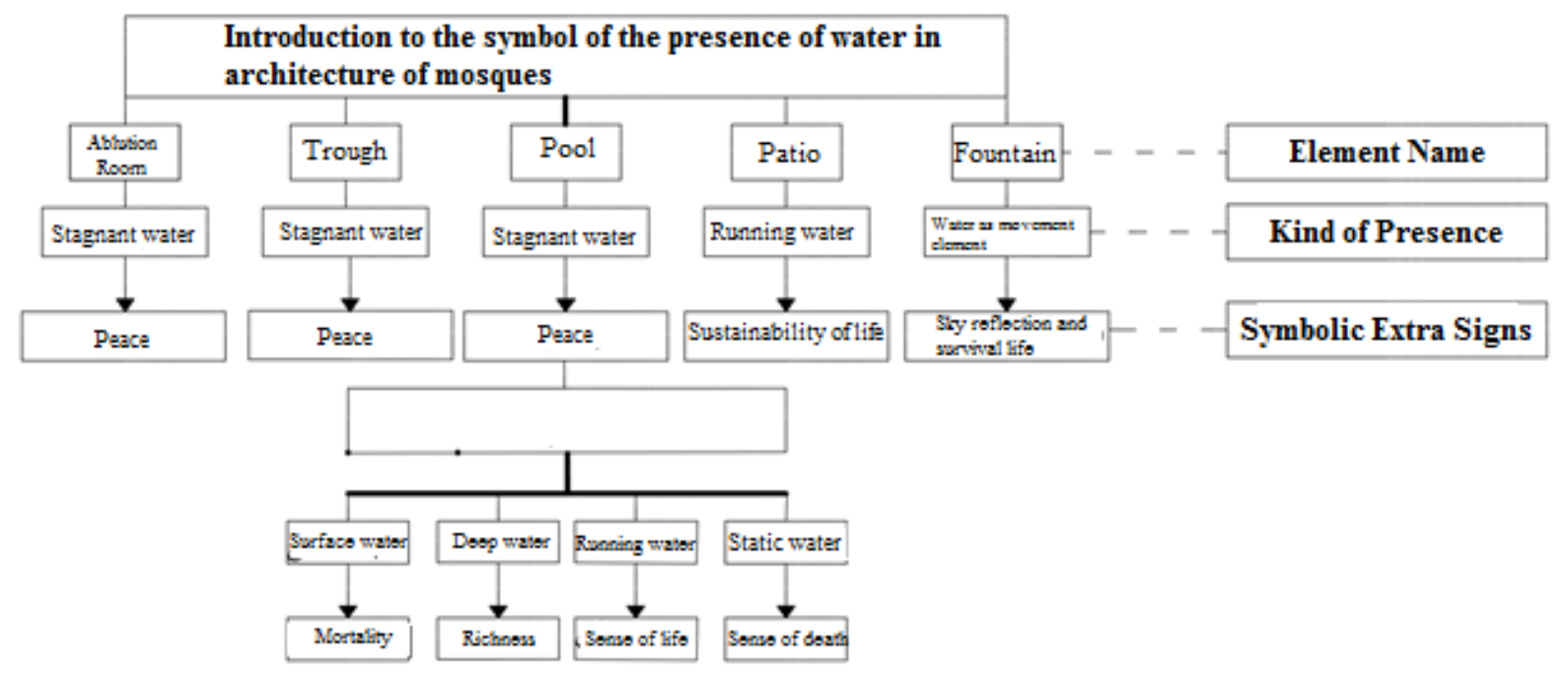

Diagram 2 Source: Based on the author's information processing

\section{CONCLUSION}

Mosque architecture in the Islamic era has formed one of the most important components of Islamic cities. On the other hand Islamic mosques architecture is one of the best built examples of the architecture in terms of artistic imagery and structural expression, and physical stability. Sociologic language has had a common and important presence in the architectural body of mosques in Islamic era. Water pond, padiav (washing and purifying a thing with praying), ablution building, large and small lavers, fountains, all have had different portraits of common symbolic symptoms in architectural language in the body of Islamic mosques in Iran.

The water element due to being soft, flowing, and fluid, and being used in various forms ranging from and used in a different way from stillness to various types of movement and motion has had an evident manifestation in mosques in Iran. Artistic semiologic interpretations of the presence of water in Iranian mosques makes possible the re-drawing and continuity of a certain kind of attitude to privacy of presence of water in Iranian mosques architecture makes where traces of views based on the wisdom of Islamic art can be seen. The present study by focusing on preliminary understanding of semiology of the presence of water in Iranian mosques architecture has tried to achieve a deeper understanding of this concept.

\section{REFERENCES}

Ariyai, Ismail, (2005), the first Seminar of art and elements of nature (water, earth, fire, air), Tehran, published by the Academy of Arts.

Ardalan Nader, Laleh Bakhtiar, (2015), the sense of unity of the role of tradition in Iranian architecture, translations Jalili Journal, Fifth Edition, Tehran science royal architect.

Abouzari, d. (2001) Introduction to Art and Cultural Heritage of Iran, Tehran, cultural research organization.

Bemanian MR, Azimi SF, (2010), "reflect on the meaning derived from the Islamic world in architectural design", Studies in Islamic Iran, No. 2, page 39 to page 48.

Dastjerdi Hosseini, M., (2013), "Principles of Islamic architectural symbolism and meaning and its impact on the Islamic city 'Islamic architecture and urbanism.

Haghighat Bin Mahdi, Ali M., (2014), "Symbolism in the Persian garden in the Islamic period and its relationship with religious beliefs makers", the role of the World, Volume 4, Number 1; Page 47 to page 55. 
Zekrgo, or. H. (2001) in the history of art course (1), Tehran, cultural research organization.

Rabii, H., (2014), Studies in the nature of Islamic Art, Tehran: Institute of authoring, translation and publishing the text of art.

Sharifian Mahdi, Darbidi Yusef, (2007), "The apple symbol, dove, rose and lily of the lyrics Sepehri", Journal of Literature and Human Sciences, No. 21, page 1 to page 26.

Teyghani Eshagh, Ghorbani Rahman, (2011), "Analysis of the reflection in the water mythological Shahnameh", a traditional Persian literature, Issue I, page 69 to page 86.

Tabatabaei, Seyyed Mohammad Hossein, (1968), Sharif Al-Mizan Commentary, Volume 32, Mohammadi, Tehran.

Ali Pourmand, H., (2014), "Architecture in the presence of water", Monthly Art, No. 189, page 18 to page 26.

Fattahy Shamsollah, Omranipour Ali, (2014), "Analysis of the Role of Qibla in the spatial organization of Ilam contemporary mosques," Islamic architectural study, first year, second edition, page 95 to page 111.

Ghaiyoomi Bandi Hindi, M., (2009), "Parygin modes of tears to the presence of water in the Persian prose texts", gallery, Volume 18, Issue 48, pp. 53-64

Working Group, (1999), Proceedings of the Symposium on Mosque Architecture: Past, Present, Future, Gharechamani Mohammad, Tehran Art University.

16. Mohseni Nia Nasser, Amiri-Far A., (2014), "From Helmand to the Tiber: the mythical water decoding and Shahnameh Aeneid of Virgil", Journal of Literature and Language, Vol. 17, No. 35, page 1 to page 27.

Motahari, (martyr) M., (1988), the problem of knowledge, Sadra, Tehran

Mahmoudi Nejad, H., (2011), bio-based architecture, Tehran: Tahan, food, Second Edition

Mansoori, Amir, (2009), "Water architecture" perspective, Issue 1, page 2 to page 3.

Corbin, Henry (2000), the man of light in Iranian Sufism, Golban publisher

Chambers. (1900). Etymological Dictionary of the English Language. (A. Findlater, Ed.) London \& Edinburgh: W. \& S. Chamberse

Colman, s. (2003), "harmonic proportion and form in nature", art and architecture, Ed Dover publication Inc, ited and with a mathematical analysis byc: Arthur coan, New York mineoia.

Jung, Carl Gustav, (1971), psychological types, translated by: Richard Francis Carrington hull, helton Godwin baynes, routledge and k.paul.

Liddell, \& Scott. (1940). A Greek-English Lexico. Oxford: Clarendon PressMuri, W. (1976). Symbolon, In Griechische Studien. In age of Classical Studies (Vol. Vol. 14). Basel: Friedrich Reinhardt Nasr, Seyed Hossein (1980), religion and the other of nature, Tehran, Kharazmi publisher Ritter, J., founder, K. F., \& Gabriel, G. (Eds.). (1998). Historisches Wörterbuch der -Philosophie (HWPh) (Vols. 10: St-T). University of Chicago Press

GÖKTAS KAYA, Lütfiye, (2015), Semiology in the teaching of history of art, Procedia - Social and Behavioral Sciences 174, 3350 - 3357

Gagiu Pedersen, Elena, (2015), Semantics of the symbol: main theories about the symbol and the themes of symbols in Alexandru Macedonski's poetry, Procedia - Social and Behavioral Sciences 180, 586 - 592

Nazidizajin Sajjad, ToméAna, RegateiroFrancisco, (2015), "Does the smartest designer design better? Effect of intelligence quotient on students' design skillsin architectural design studio", CERIS, DECivil, Instituto Superior Técnico, Universidade de Lisboa, Lisboa 1049- 001, Portugal 